Jurnal Pendidikan dan Pemberdayaan Masyarakat
Volume 3 - Nomor 1, Maret 2016, (6o-74)

\title{
EVALUASI PROGRAM KECAKAPAN HIDUP DI SANGGAR KEGIATAN BELAJAR BANTUL, YOGYAKARTA
}

\author{
Muhammad Adil Arnady ${ }^{1)}$, Iis Prasetyo ${ }^{2)}$ \\ ${ }^{1}$ Jl.Kr. Bronto Tanganga No.63 Makasar, Indonesia. Email: arnady55@gmail.com \\ ${ }^{2}$ Pendidikan Luar Sekolah, Universitas Negeri Yogyakarta, Jl. Colombo No. 1 Karangmalang, \\ Yogyakarta 55281, Indonesia Email: aa115prass@yahoo.com
}

\begin{abstract}
Abstrak
Penelitian ini bertujuan untuk mengevaluasi: (1) hasil jangka panjang program kecakapan hidup, (2) hasil jangka menengah program kecakapan hidup, (3) hasil program kecakapan hidup, (4) proses program kecakapan hidup,(5) masukan program kecakapan hidup di SKB Bantul. Penelitian ini adalah jenis penelitian evaluasi yang merujuk pada konsep Logical Framework Models. Hasil penelitian ini menunjukan: (1) hasil jangka panjang kursus rias pengantin dan komputer telah tercapai sesuai kriteria namun tidak pada kursus menjahit. (2) hasil jangka menengah kursus rias pengantin dan komputer telah tercapai sesuai kriteria keberhasilan namun tidak pada kursus menjahit. (3) hasil kursus rias pengantin dan komputer telah tercapai sesuai kriteria keberhasilan namun tidak pada kursus menjahit. (4) proses belum sepenuhnya dilaksanakan secara optimal, yaitu sosialisasi kegiatan menggunakan media internet belum optimal serta kegiatan monitoring dan evaluasi belum dilakukan secara menyeluruh. Monitoring dan evaluasi hanya terbatas pada evaluasi pembelajaran, dan belum mencakup monitoring dan evaluasi pada tataran program (5) masukan belum sepenuhnya mendukung pelaksanaan kegiatan, terutama terkait dengan permasalahan penyediaan sarana prasarana dan pendanaan kegiatan.
\end{abstract}

Kata Kunci: evaluasi, program kecakapan hidup, Logical Framework Models

\section{AN EVALUATION OF LIFE SKILLS PROGRAMS IN BANTUL LEARNING ACTIVITIES ATELIER, YOGYAKARTA}

\begin{abstract}
This study aims to analyze the evaluation of: (1) the long term results, (2) the mid-term results, (3) result, (4) process, and (5) inputs of life skills programs in SKB Bantul. This esearch was qualitative evaluation research referring to the concept of Logical Framework Models. The results of the research reveal that: (1) The long-term results of bridal make-up and computer courses have been achieved according to the criteria, but not in a sewing cours;. (2) the results of mid-term course of bridal make-up and computer courses have been achieved according to the criteria of success, but not in the sewing course; (3) the result of bridal make-up and computer courses have been achieved according to the criteria of success, but not in sewing course; (4) the process have not been fully implemented optimally, in which, neither promotion of the activities using the internet media nor monitoring and evaluation has been done optimally. Monitoring and evaluation are limited to the evaluation of learning, and not including monitoring and evaluation at program level yet; (5) the input does not comprehensively support the implementation of the activities, especially those related to supplying of infrastructure and budgeting/financing.
\end{abstract}

Keywords: evaluation, life skills programs

How to Cite: Arnady, M., \& Prasetyo, I. (2016). Evaluasi program kecakapan hidup di sanggar kegiatan belajar Bantul, Yogyakarta. Jurnal Pendidikan dan Pemberdayaan Masyarakat, 3(1), 60-74. Retrieved from http://journal.uny.ac.id/index.php/jppm/article/view/6303 
Jurnal Pendidikan dan Pemberdayaan Masyarakat, 3 (1), Maret 2016 - 61

Muhammad Adil Arnady, Iis Prasetyo

\section{PENDAHULUAN}

Mencetak sumber daya manusia yang handal adalah prasayarat mutlak bagi kemajuan suatu bangsa. SDM yang handl diharapkan dapat menjadi agen-agen pembangunan yang dapat mengurai jerat kemiskinan di Indonesia. Untuk dapat mencetak SDM yang handal diperlukan pula pendidikan yang berkualitas. Undang-Undang No. 20 Tahun 2003 tentang Sistem Pendidikan Nasional membagi jalur pendidikan di Indonesia menjadi tiga, yaitu pendidikan formal, nonformal, dan informal. Namun demikian, pada kenyatannya perhatian pemerintah masih menitikberatkan pada pendidikan formal saja. Hal ini mengakibatkan pengembangan pendidikan nonformal tidak berjalan secara maksimal, baik di tingkat pusat (makro), provinsi (meso), maupun kabupaten/kota (mikro). Padahal pendidikan nonformal memiliki kesetaraan dengan pendidikan lainnya.

Pendidikan nonformal adalah pendidikan kesetaraan yang berfungsi sebagai pengganti, penambah, dan/atau pelengkap pendidikan formal dalam rangka life long education. Bahkan berbagai penelitian membuktikan bahwa pendidikan nonformal hadir untuk menjawab hal-hal yang tidak dapat dijangkau oleh pendidikan formal. Kurikulum penting yang dibawa oleh pendidikan nonformal adalah pendidikan kecakapan hidup. Nelson-Jones (2005, p.419) menyebutkan bahwa secara netral kecakapan hidup merupakan urutan pilihan yang dibuat seseorang dalam bidang keterampilan yang spesifik.Kecakapan hidup sejatinya hadir untuk menangani dan mengurangi keterbelakangan sosial baik kemiskinan dan pengangguran yang berpotensi pada tindakan kriminal. Ihejirika (2012, p.29) menyatakan pendidikan formal saja tak cukup untuk mengatasi masalah kelaparan, penganguran, dan kemiskinan di abad 21. Untuk itu, pendidikan kecakapan hidup melalui jalur pendidikan nonformal harus dihadirkan terutama bagi orang dewasa terutama di daerah-daerah pinggiran. Pendidikan kecakapan hidup melalui jalur nonformal tersebut diharapkan mampu meningkatkan kemampuan personal, kondisi kesehatan, standar hidup, serta kemampuan ekonomi individu. Untuk itu, pendidikan kecakapan hidup melalui jalur pendidikan nonformal harus dihadirkan terutama bagi orang dewasa terutama di daerah-daerah pinggiran. Pendidikan kecakapan hidup melalui jalur nonformal tersebut diharapkan mampu meningkatkan kemampuan personal, kondisi kesehatan, standar hidup, serta kemampuan ekonomi individu.

Salah satu bentuk pelaksanaan program kecakapan hidup (life skill)dalam pendidikan nonformal adalah melalui Sanggar Kegiatan Belajar (SKB). Pelaksanaan life skill di SKB dilaksanakan pada seluruh daerah yang ada di Indonesia termasuk Kabupaten Bantul yang berada dalam lingkup Dinas Pendidikan Kabupaten Bantul. SKB Bantul sebagai penyelenggara program pelatihan kecakapan hidup diharapkan mampu memberikan kesempatan belajar bagi masyarakat agar memperoleh pengetahuan, keterampilan dan menumbuhkembangkan sikap mental kreatif, inovatif, bertanggung jawab serta berani menanggung risiko (sikap mental professional). Untuk itu, SKB Bantul menyelenggarakan berbagai bentuk pendidikan kecakapan hidup diantaranya kursus tata rias pengantin, kursus menjahit, dan kursus komputer. Untuk dapat menilai kinerja penyelenggaraan ketiga jenis kursus, perlu dilakukan pengamatan secara mendalam untuk menemukan kekurangan yang ada, sehingga SKB Bantul dapat melakukan langkah penyempurnaan pelaksanaan program. Oleh karena itu perlu dilakukan evaluasi terhadap program SKB Bantul khususnya program kecakapan hidup. Melalui evaluasi, diharapkan mampu menemukan masalah-masalah yang ada dalam program pelatihan yang menyebabkan program tersebut tidak sesuai dengan tujuan awalnya guna mengefektifkan dan mengefisienkan program pelatihan.

Undang-Undang Sistem Pendidikan Nasional No. 20 tahun 2003 Pasal 13 menjelaskan bahwa ada tiga jalur pendidikan yang dapat ditempuh oleh warga negara yaitu pendidikan formal, informal, dan nonformal. Ketiga jalur pendidikan ini memiliki kedudukan sama. Supriadi \& Jalal (2005, p.33) menjelaskan bahwa pendidikan nonformal adalah jalur pendidikan di luar pendidikan formal yang dapat dilaksanakan secara 


\section{Jurnal Pendidikan dan Pemberdayaan Masyarakat, 3 (1), Maret 2016 - 62}

Muhammad Adil Arnady, Iis Prasetyo

terstruktur dan berjenjang. Hasil pendidikan nonformal dapat dihargai setara dengan hasil program pendidikan formal setelah melalui proses penilaian penyetaraan oleh lembaga yang ditunjuk oleh pemerintah atau pemerintah daerah dengan mengacu pada standar nasional pendidikan

Pendidikan nonformal adalah suatu kebutuhan karena di negara manapun. Pendidikan nonformal diperlukan bagi mereka yang memerlukan layanan pendidikan sebelum mereka masuk sekolah, sesudah mereka menyelesaikan sekolah, ketika mereka tidak mendapat kesempatan sekolah bahkan ketika mereka sedang bersekolah. Pendidikan nonformal menitikberatkan pendekatannya pada individu dan pengembangan sosial dimana titik berat pendekatannya berada pada kelompok atau masyarakat sebagai kelompok. Pendidikan nonformal memiliki peran penting dalam pembangunan nasional. Tugas utama pendidikan nonformal adalah sebagai komplemen atau pelengkap, pengganti, dan penambah pendidikan formal, terutama bagi masyarakat yang ingin menambah pengetahuan selain yang didapatkan dari sekolah formal, drop out, atau bahkan yang tidak pernah bersekolah sama sekali

Tim Board Based Educations (Departemen Pendidikan Nasional, 2001, p.9) menyatakan bahwa kecakapan hidup (life skills) adalah kecakapan yang dimiliki seseorang untuk berani menghadapi problema hidup dan kehidupan dengan wajar tanpa merasa tertekan, kemudian secara proaktif dan kreatif mencari serta menemukan solusi sehingga akhirnya mampu mengatasinya. Pendidikan berorientasi kecakapan hidup bagi peserta didik adalah sebagai bekal dalam menghadapi dan memecahkan problema hidup dan kehidupan, baik sebagai pribadi yang mandiri, warga masyarakat, maupun sebagai warga negara.

Tim Broad Based Educations (Departemen Pendidikan Nasional, 2002, p.5) mengemukakan bahwa tujuan pendidikan kecakapan hidup adalah untuk (1) mengaktualisasikan potensi sehingga dapat memecahkan problema, (2) memberikan potensi kesempatan kepada penyelenggara untuk mengembangkan pembelajaran yang fleksibel, dan (3) mengoptimalkan pemanfaatan sum- ber daya yang ada di masyarakat. Pendidikan kecakapan hidup memberikan manfaat pribadi peserta didik dan manfaat sosial bagi masyarakat. Bagi peserta didik, pendidikan kecakapan hidup dapat meningkatkan kualitas berpikir, kualitas kalbu, dan kualitas fisik. Peningkatan kualitas tersebut pada gilirannya akan dapat meningkatkan pilihanpilihan dalam kehidupan individu, misalnya karir, penghasilan, pengaruh, prestise, kesehatan jasmani dan rohani, peluang, pengembangan diri, kemampuan kompetitif, dan kesejahteraan pribadi.

Bagi masyarakat, pendidikan kecakapan hidup dapat meningkatkan kehidupan yang maju dan madani dengan indikatorindikator adanya peningkatan kesejahteraan sosial, pengurangan perilaku destruktif sehingga dapat mereduksi masalah-masalah sosial, dan pengembangan masyarakat yang secara harmonis mampun memadukan nilainilai religi, teori, solidaritas, ekonomi, kuasa dan seni (cita rasa).

AS Horbnby (Fakhrudin, 2011, p.1) mendefiniskan evaluasi adalah to find out, decide the ammount or value yang artinya suatu upaya untuk menentukan nilai atau jumlah. Kegiatan evaluasi harus dilakukan dengan hati-hati dalam melakukan strategi sehingga dapat dipertanggungjawabkan. Evaluasi merupakan bagian dari sistem manajemen yaitu perencanaan, organisasi, pelaksanaan, monitoring dan evaluasi.

Dalam melakukan sebuah evaluasi perlu diketahui alasan-alasan untuk melakukan evaluasi tersebut. Seperti yang dijelaskan oleh Kirkpatrick \& Kirkpatrick (2006, p.17) bahwa ada tiga alasan yang perlu diketahui dalam melakukan evaluasi, (1) untuk membenarkan keberadaan dan anggaran dari departemen pelatihan dengan menunjukkan bagaimana kon-tribusi untuk tujuan dan sasaran organisasi. (2) untuk memutuskan apakah akan melanjutkan atau menghentikan program pelatihan. (3) untuk mendapatkan informasi tentang bagaimana meningkatkan program pelatihan di masa depan.

\section{METODE}

Penelitian ini adalah penelitian evaluatif. Metode evaluatif dalam penelitian ini bermaksud menjelaskan tentang adanya 


\section{Jurnal Pendidikan dan Pemberdayaan Masyarakat, 3 (1), Maret 2016 - 63 \\ Muhammad Adil Arnady, Iis Prasetyo}

program pelatihan kecakapan hidup yang sifatnya mengevaluasi dampak (jangka panjang, menengah dan keluaran), tindakan, dan masukan melalui prosedur evaluasi secara ilmiah dalam mengumpulkan dan menganalisis data untuk menentukan nilai dan manfaat dari suatu program pelatihan.

Data penelitian dikumpulkan dengan metode wawancara mendalam, observasi, dan dokumentasi model evaluasi yang digunakan dalam penelitian ini adalah logical framework. Logical Framework adalah alat untuk perencanaan, monitoring dan evaluasi dari project/program, Logical Framework digunakan untuk melihat keberhasilan ataupun ketidaktercapaian suatu program dari result atau hasil; Impact (jangka panjang), outcomes (menengah) dan outputs (produk); Activities (kegiatan) dan input (keuangan, manusia, sumber daya material). Untuk memfokuskan tahapan-tahapan proses evaluasi, digunakan alat Logframe Matrux. Logframe Matrux merupakan hasil dari analisis yang menyajikan ringkasan apa yang menjadi tujuan program dan bagaimana melakukannya, apa yang menjadi asumsi dasar, dan bagaimana output dan outcome dimonitor dan dievaluasi. Berikut ini Logframe Matrux ketiga jenis kursus. Adapun logframe matrix ketiga jenis kursus sebagai berikut.

\section{HASIL DAN PEMBAHASAN}

\section{Evaluasi Hasil Jangka Panjang Program Kecakapan Hidup}

Hasil jangka panjang sesuai yang diharapkan telah berhasil dicapai dari penyelenggaraan kursus tata rias pengantin dan kursus komputer, namun tidak demikian dengan penyelenggaraan kursus menjahit. Seluruh informan kursus rias pengantin menyatakan telah telah memanfaatkan keterampilan yang diperolehnya selama mengikuti kursus rias pengantin dengan membuka usaha jasa rias pengantin. Usaha jasa rias pengantin yang dijalankannya dapat memberikan penghasilan yang lebih baik daripada sebelumnya. Peserta juga telah dapat membuka lapangan usaha untuk orang lain, walaupun sifatnya adalah karyawan freelance. Karyawan freelance yang dipeker- jakan oleh peserta akan mendapatkan penghasilan sebesar jasa yang diberikan dan banyaknya pekerjaan yang dilakukan.

Sebagian besar peserta kursus komputer telah dapat memanfaatkan keterampilan komputer yang diperolehnya dalam pekerjaan yang dilaksanakannya sehari-hari. Walaupun tidak mendatangkan tambahan penghasilan, namun keterampilan yang dimiliki dapat mengurangi biaya yang sebelumnya harus dikeluarkan, yaitu biaya rental pengetikan komputer. Untuk penyelenggaraan kursus menjahit, diketahui bahwa tidak ada satupun peserta kursus menjahit SKB Bantul TA 2012 yang memanfaatkan ilmu yang diperolehnya selama mengikuti kursus untuk membuka lapangan kerja ataupun memperkerjakan orang lain. Tidak seorang pesertapun yang mampu memperoleh penghasilan tambahan dari keterampilan menjahit yang diperolehnya selama kursus.

Pada kursus rias pengantin, sebelum mengikuti kursus peserta umumnya memang telah berkecimpung di bidang tata rias ataupun usaha salon yang terkait dengan tata rias. Peserta umumnya telah mempunyai pengalaman menjadi freelance di usaha rias pengantin di tempat lain,walaupun bukan sebagai perias utama. Pengalaman yang telah dilalui peserta sebegai freelance jasa rias pengantin telah membuka wawasan peserta, bahwa peserta memang tertarik lebih dalam untuk berkecimpung di usaha rias pengantin. Hal tersebut akan mempengaruhi motivasi peserta yaitu peserta mengikuti kursus rias pengantin memang untuk menambah keterampilannya sehingga suatu hari nanti dapat membuka sendiri usaha rias pengantin.

Demikian pula dengan peserta kursus komputer. Peserta kursus komputer umumnya telah bekerja yang dalam pekerjaannya membutuhkan keahlian mengoperasikan komputer. Tanpa adanya keahlian tersebut, peserta akan mengalami inefisensi kerja, yaitu harus selalu bergantung kepada orang lain dan harus selalu mengeluarkan biaya yang lebih. Masalah inefisiensi kerja telah mendorong peserta untuk dapat menguasai aplikasi dasar komputer. Hal tersebut cukup memotivasi peserta dalam mengikuti jalannya kursus. 


\section{Jurnal Pendidikan dan Pemberdayaan Masyarakat, 3 (1), Maret 2016 - 64 \\ Muhammad Adil Arnady, Iis Prasetyo}

Berbeda dengan kursus rias pengantin dan kursus komputer, peserta kursus menjahit umumnya belum mempunyai latar belakang menjahit sama sekali. Keikutsertaan peserta dalam kursus menjahit dilandasi motivasi ingin mengisi waktu luang saja. Pada saat mengikuti kursus, peserta belum mempunyai tujuan, apakah menjahit nantinya akan menjadi usaha bisnisnya di masa mendatang. Hal tersebut mengandung arti bahwa peserta masih dalam taraf coba-coba dalam menggali minatnya di bidang menjahit.

\section{Evaluasi Hasil Jangka Menengah Prog- ram Kecakapan Hidup}

Sama halnya dengan pencapaian tujuan jangka panjang, hasil jangka menengah yang diharapkan telah berhasil dicapai oleh kursus rias pengantin dan kursus komputer, namun tidak berhasil dicapai dari penyelenggaraan kursus menjahit. Sama halnya dengan pencapaian tujuan jangka panjang, faktor utama yang menentukan keberhasilan pencapaian tujuan jangka menengah adalah faktor peserta. Baik peserta kursus tata rias ataupun kursus komputer, umumnya telah mempunyai pekerjaan ataupun usaha yang membutuhkan keahlian tata rias pengantin dan komputer. Keikutsertaan peserta dalam kursus memang dilandasi motivasi ingin menguasai keterampilan tersebut sehingga dapat diaplikasikan pada pekerjaannya, sehingga dapat menambah penghasilan ataupun menambah efektifitas kerja

Lain halnya dengan peserta kursus menjahit, peserta kursus menjahit tidak ada satupun yang bekerja di bidang menjahit. Peserta tidak berusaha melamar pekerjaan di tempat usaha menjahit karena merasa tidak menguasai keterampilan menjahit.

\section{Evaluasi Hasil Program Kecakapan Hidup}

Hasil program kecakapan hidup sesuai yang diharapkan telah berhasil dicapai dari penyelenggaraan kursus tata rias pengantin dan kursus komputer, namum belum berhasil diraih dari penyelenggaraan kursus menjahit.
Peserta Pelatihan Memiliki Kecakapan Pribadi

Anwar (2012, p.29) menyatakan kecakapan personal mencakup kecakapan dalam memahami diri (self awareness skill) dan kecakapan berpikir (thinking skill). Kecakapan mengenal diri pada dasarnya merupakan penghayatan diri sebagai makhluk Tuhan Yang Maha Esa, sebagai anggota masyarakat dan warga negara, serta menyadari dan mensyukuri kelebihan dan kekurangan yang dimiliki sekaligus sebagai modal dalam meningkatkan dirinya sebagai individu yang bermanfaat bagi lingkungannya. Kecakapan berpikir (thinking skill) mencakup kecakapan mengenali dan menemukan informasi, mengolah, dan mengambil keputusan, serta memecahkan masalah secara kreatif.

Kaitannya dengan hubungannya dengan Tuhan, adanya kecakapan tersebut tampak jelas pada sikap mental peserta kursus tata rias. Hal tersebut sesuai dengan tuntutan pekerjaan usaha rias pengantin yang di dalamnya penuh dengan unsurunsur tradisional dan keagamaan.

Sebagian besar peserta kursus rias pengantin saat ini telah mempunyai usaha di bidang tata rias pengantin. Adanya keputusan tersebut juga menunjukkan bahwa peserta cukup mempunyai kecakapan memahami diri sendiri (self awareness skill) yaitu memahami kekurangan dan kelebihan yang dimilikinya serta berupaya mengelola kekurangan yang dimilikinya untuk mengembangkan dirinya menjadi pribadi yang bermanfaat. Keberanian untuk memutuskan dan membuka usaha di bidang rias pengantin juga menunjukkan bahwa peserta cukup mempunyai kemampuan berpikir, yaitu kemampuan untuk membuat dan menganalisis berbagai macam kondisi berdasarkan informasi yang dimilikinya, mengolah infromasi tersebut, dan memutuskan membuka usaha/ bekerja di bidang tata rias pengantin dengan segala resiko dan keuntungannya

Demikian pula dengan peserta kursus komputer. Kecakapan dalam memahami diri sendiri (self awareness skill) peserta kursus komputer tampak dengan adanya kesadaran atas kekurangan yang dimilikinya, dan adanya perasaan tidak mau merepotkan dan 


\section{Jurnal Pendidikan dan Pemberdayaan Masyarakat, 3 (1), Maret 2016 - 65}

Muhammad Adil Arnady, Iis Prasetyo

bergantung kepada orang lain untuk dapat menyelesaikan pekerjaan sehari-harinya. Adanya kemampuan tersebut dibarengi dengan kecakapan berpikir, yaitu kemampuan untuk mencari solusi atas kekurangan yang dimilikinya dengan mengikuti kursus komputer, mengikuti tahapan dan materi kursus dengan baik, hingga akhirnya dapat memecahkan masalah dengan menerapkan ilmu yang dimilikinya pada pekerjaan sehari-hari.

Berbeda dengan peserta kursus menjahit, pada dasarnya peserta kursus menjahit mempunyai kecakapan memahami diri sendiri, yaitu kemampuan untuk mengenali kekurangan dan kelebihan yang dimilikinya untuk menghadapi masa depan. Peserta pada umumnya belum memutuskan untuk membuka usaha di bidang menjahit, namun demikian dengan mengikuti kursus menjahit peserta berusaha membekali dirinya dengan ilmu yang berguna baginya di masa depan. Kecakapan memahami diri sendiri tersebut sayangnya tidak dibarengi dengan kecakapan berpikir yang optimal. Beberapa peserta menyatakan berhenti sebelum menyelesaikan tahapan pembelajaran dan tidak mengikuti ujian karena merasa tidak dapat mengolah infromasi dan mengasah keterampilannya di bidang menjahit. Sikap mental tersebut menunjukkan bahwa peserta belum cukup mempuyai kecakapan personal, yaitu belum mampu mengelola kekurangan dan kelebihan yang dimilikinya untuk memecahkan masalah secara kreatif.

\section{Peserta Pelatihan Memiliki Kecakapan Sosial}

Anwar (2012, p.30) menyatakan kecakapan sosial mencakup kecakapan berkomunikasi dengan empati (communication skill) dan kecakapan bekerjasama (collaboration skill). Berkomunikasi dengan empati yang dimaksud adalah berkomunikasi bukan sekedar menyampaikan pesan namun isi dan sampainya pesan disertai dengan kesan baik yang akan menumbuhkan hubungan yang harmonis.

Adanya kecakapan sosial tampak dihasilkan dari penyelenggaraan kursus rias pengantin. Berdasarkan pernyataan para peserta, selama masa kursus komunikasi antar peserta terjalin dengan baik. Terjadi proses saling bekerjasama terutama pada saat dilakukannya praktek dan saling mengingatkan satu sama lain apabila terdapat kesalahan. Komunikasi dengan narasumber/tutor juga berjalan dengan baik. Peserta bebas menanyakan hal-hal yang tidak diketahuinya selama pelatihan kepada narasumber. Pasca pelatihan, komunikasi tetap terjalin melalui paguyuban alumni SKB Bantul melalui paguyuban Pandan Wangi. Anggota paguyuban saling bersilaturahmi dan mengadakan kegiatan arisan setiap bulannya. Pada saat dilaksanakannya arisan, dilakukan pula sharing ilmu seperti tips menggunakan jilbab, cara make up modern, dan keterampilan-keterampilan lainnya. Kerjasama juga terjadi antar sesama peserta dalam menjalani dunia usaha. Apabila terdapat pekerjaan ataupun pesanan yang tidak dapat ditangani sendiri, seringkali peserta memanfaatkan jasa peserta lain untuk membantunya melayani pesanan.

Berbeda dengan kursus rias pengantin, peserta kursus komputer dan menjahit umumnya tidak lagi menjalin hubungan dengan peserta yang lain pasca pelatihan. Namun demikian, berdasarkan pernyataan dari narasumber dan peserta, diketahui bahwa selama proses pelatihan tampak perubahan sikap dari diri peserta, dari yang semula malu-malu, menjadi lebih berani untuk bertanya dan mengemukakan pendapat selama pelatihan. Hal tersebut tak lepas dari peranan narasumber yang berhasil menciptakan suasana kekeluargaan selama pelatihan, sehingga peserta tidak sungkan untuk bertanya. Kerjasama dengan sesama peserta juga tercipta, misalnya pada saat praktek menjahit, sesama peserta saling membantu mengukur badan peserta lainnya untuk dibuatkan baju.

\section{Peserta Pelatihan Memiliki Kecakapan Akademik}

Anwar (2012, p.30) menyatakan bahwa kecakapan akademik pada dasarnya adalah pengembangan dari kecakapan berpikir, namun kecakapan akademik lebih mengarah kepada kegiatan yang bersifat akademik/ keilmuan. Kecakapan akademik mencakup antara lain kecakapan melakukan identifikasi variabel dan menjelaskan hubungannya pada suatu fenomena tertentu, merumuskan 


\section{Jurnal Pendidikan dan Pemberdayaan Masyarakat, 3 (1), Maret 2016 - 66}

Muhammad Adil Arnady, Iis Prasetyo

hipotesa terhadap suatu rangkaian kejadian, serta merancang dan melaksanakan penelitian. Penerapannya pada kegiatan kursus, penguasaan kecakapan akademik ditunjukkan dengan penguasaan materi kursus yang nantinya diterapkan dalam praktek keahlian.

Pada penyelenggaraan kursus, pengukuran akan kecakapan akademik dilakukan pada saat evaluasi pembelajaran yaitu pada saat dilaksanakannya ujian. Khusus untuk penyelenggara kursus tata rias pengantin, ujian dilaksanakan dua kali, yaitu ujian lokal dan ujian kompetensi. Adapun materi yang diujikan meliputi teori dan praktek. Pada penyelenggraan kursus komputer, ujian yang dilakukan hanyalah ujian lokal dengan materi ujian meliputi ujian teori dan praktek, sedangkan pada penyelenggaraan kursus menjahit, ujian yang dilakukan adalah ujian lokal dengan materi ujian praktek.

Peserta yang lulus ujian, baik ujian lokal maupun ujian praktek menunjukkan bahwa peserta tersebut mempunyai kecakapan akademik. Pada kursus menjahit, walaupun tidak terdapat ujian teori, namun peserta yang lulus ujian praktek menunjukkan bahwa peserta tersebut memahami teori menjahit sehingga dapat menerapkannya dalam ujian praktek. Peserta kursus rias pengantin dan kursus komputer seluruhnya mengikuti ujian lokal dan dinyatakan lulus, sedangkan peserta kursus menjahit sebagian besar tidak mengikuti ujian lokal, bahkan berhenti mengikuti kursus sebelum masa pembelajaran berakhir.

Peserta Pelatihan Memiliki Kecakapan Vokasional

Kecakapan vokasional terkait dengan bidang pekerjaan yang lebih memerlukan keterampilan motorik. Adanya kecakapan tersebut tampak jelas pada peserta kursus tata rias pengantin dan peserta kursus komputer yang mana peserta kedua jenis tersebut dapat lulus pada ujian praktek dan setelah mengikuti kursus mampu mengapilikasikan keterampilan yang dimilikinya di dunia usaha. Berbeda dengan peserta kursus menjahit, seluruh informan menyatakan tidak mengikuti ujian dan bahkan tidak menyelesaikan seluruh tahapan ujian karena merasa tidak cukup mempunyai keterampilan di bidang menjahit. Hal tersebut menunjukkan bahwa peserta tidak cukup mempunyai kecakapan vokasional.

Penelitian yang dilakukan atas pencapaian hasil jangka penjang, hasil jangka menengah, dan hasil jangka pendek menunjukkan pencapaian yang selaras. Baik kursus tata rias pengantin dan kursus komputer berhasil mencapai tujuan jangka panjang, jangka menengah, maupun jangka pendeknya, namun tidak demikian dengan kursus menjahit. Kursus menjahit tidak berhasil mencapai tujuan jangka panjang, jangka menengah, dan jangka pendek. Pada proses pendidikan orang dewasa, keberhasilan pencapaian tujuan sangat dipengaruhi oleh proses belajar. Suprijanto (2012, pp.4043) menjelaskan bahwa proses belajar adalah sebuah proses yang terjadi pada internal diri seseorang dan tidak tampak secara lahiriah. Proses internal tersebut terdapat pada pikiran seseorang dan apabila proses belajar telah terjadi, sesuatu yang bersifat tidak tampak tersebut nantinya akan tercermin dalam kondisi eksternal seseorang. Proses belajar yang terjadi dalam diri seseorang mencakup enam tahapan, yaitu: (1) motivasi; (2) perhatian pada pelajaran; (3) menerima dan mengingat; (4) reproduksi; (5) generalisasi; serta (6) melaksanakan tugas belajar dan umpan balik.

Pada pembahasan sebelumnya, telah dibahas bahwa faktor motivasi merupakan faktor utama yang menyebabkan berhasil atau tidaknya tujuan jangka panjang, tujuan jangka menengah, dan tujuan jangka pendek. Faktor motivasi tersebut pada dasarnya adalah sebuah landasan. Bersama motivasi yang kuat, maka akan timbul proses belajar yang kuat pula. Proses belajar yang kuat diindikasikan dengan adanya perhatian yang penuh ataupun fokus pada materi yang disampaikan. Setelah memperhatikan pelajaran, seseorang akan berusaha mengerti, mengingat, serta menyimpannya pada pikirannya. Hal-hal yang disimpan tersebut kemudian direproduksi kembali, disinergikan dengan ingatan-ingatan lama sehingga menimbulkan suatu ingatan yang utuh, tak hanya mengingat informasi yang baru saja diterima. Dengan mereproduksi informasi, peserta didk harus mampu menerapkan hal 


\section{Jurnal Pendidikan dan Pemberdayaan Masyarakat, 3 (1), Maret 2016 - 67 \\ Muhammad Adil Arnady, Iis Prasetyo}

yang telah dipelajari dalam ruang lingkup yang lebih luas,

Adanya hasil belajar yang berbeda antara peserta kursus tata rias pengantin dan kurusus komputer dengan peserta kursus menjahit menunjukkan adanya perbedaan dalam proses belajar yang dialami oleh para peserta. Faktor motivasi adalah yang utama. Tidak adanya visi ke depan dari peserta kursus menjahit menjadikan motivasi peserta kurang. Motivasi yang kurang tersebut akan mengganggu tahapan lainnya, yaitu proses memperhatikan pelajaran, menerima dan mengingat, reproduksi, generalisasi, dan menerapkan. Motivasi peserta yang lemah menyebabkan daya juang peserta untuk memberikan perhatian dan fokus kepada materi menjadi kurang. Beberapa peserta memutuskan menyerah untuk berusaha dengan menggangap dirinya tidak mampu untuk menguasai materi yang diajarkan.

\section{Evaluasi Proses Program Kecakapan Hidup}

Proses program kecakapan hidup penyelenggaraan kursus tata rias pengantin, kursus menjahit, dan kursus komputer dibagi dalam tiga tahapan, yaitu tahapan promosi/sosialisasi, pelaksanaan program, serta proses monitoring dan evaluasi.

\section{Tahap Promosi/Sosialisasi}

Kegiatan sosialisasi baik pada penyelenggaraan kursus tata rias pengantin, kursus komputer, maupun kursus menjahit belum dilakukan secara optimal. Perbaikan terutama harus dilakukan pada tampilan website. SKB Bantul juga perlu mengupdate secara berkala informasi kursus pada website maupun akun media sosial yang dimiliki sehingga pencarian akan informasi kursus di SKB Bantul lebih mudah diperoleh.

Berdasarkan konfirmasi yang dilakukan kepada kepala SKB Bantul, secara umum SKB Bantul melakukan sosialisasi kegiatannya melalui website resmi SKB Bantul yaitu www.skb-bantul.com. Selain melalui website SKB Bantul, SKB Bantul juga aktif mengikuti pameran/expo pembangunan yang diselenggarakan oleh pemerintah daerah. Penyelenggaraan kegiatan disosialiasikan pula melalui spanduk dan leaflet yang dibagikan kepada masyarakat pada saat acara-acara tertentu.

Berdasarkan hasil wawancara kepada penyelenggara dan peserta, strategi sosialisasi yang dilakukan oleh SKB Bantul dirasa belum efektif untuk mensosialisasikan kegiatan kursus. Dibandingkan dengan sosialisasi yang dilakukan secara formal, peserta kursus menyatakan informasi kursus lebih banyak diperoleh dari informasi mulut ke mulut.

Terkait dengan sosialisasi melalui media internet, info tentang penyelenggaraan kursus tersebut di SKB Bantul melalui mesin pencarian (www.google.com) tidak dapat dapat segera ditemukan. Demikian pula pada website resmi SKB Bantul, informasi kursus juga tidak dapat segera ditemukan dalam website tersebut. Hal tersebut juga dialami oleh peserta. Peserta kursus menyatakan mengetahui adanya informasi kursus dari kerabat. Menindaklanjuti info tersebut, peserta berusaha mencari info dari website SKB Bantul namun informasi tentang kursus juga tidak dapat segera ditemukan.

Menu utama website pada website resmi SKB Bantul adalah home (beranda), profil, dan kontak kami. Terdapat pula arsip yaitu berita-berita yang diposting oleh SKB Bantul. Informasi adanya kursus dan program SKB Bantul secara umum dapat dilihat pada menu profil pada Program Kegiatan SKB Bantul. Informasi yang tertera pada bagian tersebut hanya memuat nama program, sasaran jumlah peserta, lokasi kegiatan, dan pendanaan. Tidak terdapat informasi lebih detail mengenai info penting lainnya seperti estimasi waktu penyelenggaraan kegiatan, besaran biaya, dan persyaratan pendaftaran. Informasi lebih detail tentang kursus dapat ditelusuri pada arsip sehingga sulit untuk ditemukan. Informasi juga baru diposting pada saat kegiatan telah diselenggarakan.

\section{Tahap Pelaksanaan}

Pelaksanaan kursus yang dilakukan di SKB Bantul telah mendukung proses belajar pesertaNamun demikian, mengingat adanya target peserta yang sangat besar, panitia penyelenggara perlu mempertimbangkan frekuensi penyelenggaraan kursus dan 


\section{Jurnal Pendidikan dan Pemberdayaan Masyarakat, 3 (1), Maret 2016 - 68}

Muhammad Adil Arnady, Iis Prasetyo

penambahan materi kursus untuk ketigas jenis kursus. Khusus untuk pelaksanaan kursus menjahit, penyelenggara perlu mengevaluasi efektivitas penyelenggaraan kursus yang mana peserta kursus dapat memulai kursus kapan saja.

Tahap pelaksanaan kursus adalah tahapan pada saat kursus diselenggarakan. Suasana belajar yang kondusif perlu diupayakan oleh setiap pembimbing orang dewasa agar proses belajar dapat berjalan dan lancar. Untuk menciptakan suasana tersebut, ketiga narasumber/tutor kursus menyatakan bahwa dalam melakukan interaksi di kelas, mereka menerapkan sistem kekeluargaan dan berusaha menciptkan suasana nyaman saat berada di kelas.

Narasumber/tutor kursus rias pengantin menyatakan, suasana kekeluargaan tersebut dibentuk dengan membuka komunikasi yang intensif dengan peserta. Komunikasi yang dijalin tidak terbatas pada materi kursus namun narasumber/tutor juga berusaha memahami persoalan-persaolan pribadi peserta. Adanya hubungan yang baik tersebut bahkan terus berlanjut pasca penyelenggaraan kursus yaitu melalui paguyuban alumni. Adanya suasana belajar yang kondusif juga dinyatakan oleh peserta. Peserta menyatakan bahwa narasumber/tutor adalah seorang yang tegas dan teliti. Narasumber/ tutor tak segan untuk memberikan masukan atau mengkoreski kesalahan yang dilakukan oleh peserta. Namun demikina, sikap tegas tersebut tidak membuat suasana menjadi tegang. Adanya komunikasi yang baik membuat peserta memahami bahwa tindakan yang dilakukan oleh tutor adalah untuk memupuk sikap mental peserta. Pesertapun bebas bertanya tanpa merasa segan kepada tutor/narasumber.

Pada penyelenggaraan kursus komputer, narasumber/tutor menyatakan bahwa bekal utama yang harus dimiliki oleh narasumber/tutor kursus komputer adalah kesabaran. Narasumber/tutor harus menyadari bahwa banyak diantara peserta yang sama sekali tidak mengetahui keterampilan menggunakan komputer, seperti menyalakan komputer dan menggerakan kursor. Selain itu, peserta umumnya telah mempunyai pekerjaan sehingga terkadang diantaranya tidak dapat mengikuti kursus karena tuntutan pekerjaan. Oleh karena itu, narasumber dituntut untuk telaten dan sabar dalam membimbing peserta kursus. Narasumber berusaha menciptakan kelas yang santai dan tidak formal. Untuk memecahkan kejenuhan dan kebosanan dalam pelaksanaan kelas, narasumber/tutor seringkali menyelipkan materi tentang internet dan video-video lucu. Suasana menyenangkan saat kursus juga dinyatakan oleh peserta. Peserta menyatakan bahwa naraumber/tutor sangat sabar dalam menghadapi peserta yang umumnya sudah tidak muda lagi. Suasana kelas yang nyaman juga membuat peserta tidak malu dan sungkan untuk bertanya.

Pada penyelenggaraan kursus menjahit, narasumber/tutor menjahit menggunakan metode semi privat yaitu narasumber mengamati dan mengarahkan setiap peserta dalam melakukan prose belajar sesuai kemampuan masing-masing. Metode demikian digunakan karena waktu masuk peserta kursus tidak bersamaan. Waktu pelaksanaan kursus menyebabkan terjadinya inefiensi penyelenggaraan kursus. Hal tersebut terutama terkait dengan kondisi warga belajar yaitu faktor kompetensi, pengalaman, dan motivasi. Warga belajar kursus menjahit pada umumnya belum mempunyai pengalaman dan kompetensi sama sekali di bidang menjahit. Selain ini, motivasi peserta umumnya masih bersifat coba-coba dan belum mempunyai visi akan menjalankan usaha di bidang tersebut. Metode pembelajaran yang diterapkan oleh panitia penyelenggara, yang memungkinkan peserta dapat masuk kapan saja tampaknya kurang tepat diterapkan pada situasi warga belajar yang demikian. Selain tidak efisien dari sisi penyelenggaraan program, peserta menjadi tidak fokus karena peserta merasa dapat masuk kapan saja. Peserta yang dapat masuk kapan saja membuat pelaksanaan kelas dapat saja diikuti oleh peserta dengan jumlah sedikit. Salah seorang peserta menyatakan bahwa keadaan tersebut membuat dirinya merasa bosan mengikuti pelatihan. Ujian akhir tidak dapat dilakukan secara bersamaan dan seringkali tutor harus mengulang materi karena siswa cepat lupa.

Narasumber/tutor berusaha menciptakan suasana belajar yang menyenangkan 


\section{Jurnal Pendidikan dan Pemberdayaan Masyarakat, 3 (1), Maret 2016 - 69}

Muhammad Adil Arnady, Iis Prasetyo

sehingga peserta dapat dengan leluasa melakukan komunikasi dengan narasumber/ tutor. Narasumber/tutor juga senantiasa membimbing dan memotivasi peserta untuk dapat menguasai materi yang diberikan. Namun demikian, tampaknya upaya yang dilakukan oleh narasumber/tutor kursus menjahit kurang berhasil dalam meningkatkan motivasi peserta. Hal tersebut dibuktikan dengan banyaknya peserta yang merasa tidak mampu mengikuti ujian bahkan berhenti sebelum menyelesaikan kursus karena merasa tidak mampu menguasai keterampilan menjahit.

\section{Tahap Monitoring dan Evaluasi}

Penyelenggaraan monitoring dan evaluasi pada ketiga jenis kursus belum dilakukan secara menyeluruh. Monitoring dan evaluasi ketiga jenis kursus hanya diselenggarakan pada tataran evaluasi pembelajaran, namun belum mencakup tataran program terutama untuk melihat dampak kursus. Untuk penyelenggaraan kursus menjahit dan kursus komputer, databased peserta diketahui belum ditatausahakan secara memadai.

Sudjana (2006, p.17) menyatakan terdapat banyak terdapat konsep yang salah terkait evaluasi program, yang mana menyamakan antara evaluasi pembelajaran/tes kecakapan dengan evaluasi program. Evaluasi program pada dasarnya mencakup ruang lingkup yang lebih luas daripada evaluasi pembelajaran.

Pada tahapan monitoring dan evaluasi, penyelenggara ketiga jenis kursus baru melaksanakan proses evaluasi pembelajaran saja. Pada tingkatan program, monitoring dan evaluasi telah dilaksanakan namun belum memadai. Evaluasi pembelajaran dilakukan pada akhir masa pembelajaran. Evaluasi pembelajaran dilakukan melalui ujian lokal, yaitu ujian teori dan praktek tentang pengetahuan dan keterampilan yang diperoleh peserta selama kursus. Khusus untuk peserta kursus rias pengantin, ujian ditambah lagi dengan ujian kompetensi. Ujian lokal dilakukan sendiri oleh tutor/narasumber.

Khusus untuk penyelenggaraan kursus tata rias pengantin, selain menyelenggarakan ujian lokal, peserta ikut serta pula dalam uji komptensi. Uji kompetensi dapat dilakukan di SKB Bantul karena SKB Bantul sejak tahun 2011 telah ditetapkan sebagai tempat uji kompetensi tata rias pengantin oleh Lembaga Sertifikasi Kompetensi (LSK) Tata Rias Pengantin. Uji kompetensi dilakukan oleh LSK Tata Rias Pengantin secara langsung. Peserta yang lulus uji kompetensi akan mendapatkan sertifikat kompetensi dar LSK Tata Rias Pengantin. Perolehan sertifikat uji kompetensi adalah suatu prestasi tersendiri bagi para peserta, yang mana sertifikat kompetenesi menunjukkan pengakuan atas keahlian seseorang di bidang tersebut. Dari 17 peserta kursus tata rias pengantin, 16 diantaranya mengikuti uji kompetensi dan dinyatakan lulus. Sedangkan satu orang lainnya tidak mengikuti uji kompetensi karena telah mengikuti uji kompetensi sejenis sebelumnya.

Pada tahapan monitoring dan evaluasi dalam tataran program, penyelenggara kursus tata rias pengantin, kursus komputer, dan kursus menjahit belum melakukan monitoring dan evaluasi program secara memadai. Pada laporan pertanggungjawaban penyelenggaraan kursus, penyelenggara telah mencantumkan hasil evaluasi atas pelaksanaan program beserta rencana tindak lanjutnya. Namun demikian, evaluasi tersebut hanya mencakup kendala-kendala yang dihadapi pada proses pelaksanaan kursus saja seperti uraian tentang kurangnya sosialisasi kegiatan dan kurangnya sarana prasarana. Rencana tindak lanjut untuk mengatasi kendala-kenadala yang dihadapi juga telah disusun. Namun demikian, belum terdapat proses monitoring yaitu pemantauan tindak lanjut atas rencana yang telah disusun.

Evaluasi dan monitoring pada tataran outcome belum dilakukan oleh penyelenggara kursus baik kursus tata rias pengantin, kursus komputer, maupun kursus menjahit. Interaksi antara penyelenggara dan peserta terhenti setelah ujian lokal dan uji kompetensi dilaksanakan. Evaluasi dan montoring pada tataran outcome tersebut penting dilakukan untuk mengetahui pencapaian tujuan program yaitu dapat memberdayakan masyarakat melalui keterampilan yang diperolehnya selama kursus untuk meningkatkan kesejahteraan peserta. Pada penyelenggaraan 


\section{Jurnal Pendidikan dan Pemberdayaan Masyarakat, 3 (1), Maret 2016 - 70}

Muhammad Adil Arnady, Iis Prasetyo

kursus rias pengantin, proses monitoring dan eveluasi program pada tataran outcome sebenarnya telah dilakukan secara tidak formal melalui pertemuan-pertemuan yang dilakukan di paguyuban alumni. Namun demikian, hasil atas proses tersebut tidak didokumentasikan dengan baik.

\section{Evaluasi Input Program Kecakapan Hidup}

\section{Panitia Penyelenggara}

Panitia penyelenggara ketiga jenis kursus adalah panitia yang kompeten dan profesional. Panitia penyelenggara telah ditetapkan dengan SK dan telah menjalankan tugasnya dengan baik. Namun demikian, panitia penyelenggara perlu meningkatkan kinerjanya terutama dalam proses monitoring dan evaluasi program. Khusus untuk panitia penyelenggara kursus menjahit, SKB Bantul perlu melakukan evaluasi atas kinerjanya mengingat banyaknya peserta yang berhenti kursus sebelum menyelesaikan tahapan kursus.

Panitia penyelenggara adalah eleman input yang penting dalam penyelenggaraan suatu kegiatan, termasuk dalam penyelenggaraan pendidikan nonformal. Kamil (2012, pp.6o-65) mengemukakan bahwa dalam mengembangkan program pendidikan nonformal, penyelenggara harus memperhatikan kondisi warga belajar, kondisi sumber belajar, daya dukung pemerintah, tokoh masyarakat, dan instansi lainnya, serta kemampuan kerja sama dengan pihak lain. Kondisi warga belajar dalam mengembangkan program pendidikan nonformal harus dijadikan acaun utama. Kondisi warga belajar tersebut meliputi faktor usia, pengalaman calon peserta, kompetensi peserta, dan motivasi peserta. Hal-hal tersebut perlu diperhatikan mengingat karekateristik peserta pendidikan nonformal berbeda apabila dibandingkan dengan pendidikan formal yang umumnya lebih homogen.

SKB Bantul telah memiliki pengalaman yang cukup lama dalam penyelenggaraan kursus, baik kursus tata rias, kursus menjahit, maupun kursus komputer. Secara struktural, panitia penyelenggara kursus tata rias pengantin, kursus menjahit, dan kursus komputer telah ditetapkan melalui SK Kepala SKB. Berdasarkan hasil penelitian, diketahui bahwa panitia penyelenggara telah mempunyai segala kompetensi sesuai persyaratan yang diungkapkan oleh Kamil (2012, p.46). Panitia penyelenggara telah melakukan seleksi dan memilih tutor/narasumber yang ahli di bidangnya. Panitia penyelenggara telah menyusun materi dan kurikulum serta menyediakan sarana prasana kursus. Panitia penyelenggara juga aktif berkoordinasi dengan para stakeholder, baik sebelum pelaksanaan kursus maupun pada saat pelaksanaan kursus. Kinerja panitia penyelenggara dapat ditunjukkan dari laporan pertanggungjawaban panitia penyelenggara yang di dalamnya telah memuat laporan pelaksanaan kegiatan, laporan penggunaan dana dengan disertai dengan bukti belanja, hasil evaluasi kegiatan serta rencana tindak lanjutnya.

Hal yang perlu diperhatikan adalah belum adanya kegiatan monitoring dan evaluasi program secara memadai. Berdasarkan hasil penelitian, proses monitoring dan evaluasi program terutama mengenai pengaruh yang dirasakan peserta belum dilakukan. Proses tersebut sangatlah penting untuk memastikan bahwa tujuan pencapaian program terutama tujuan jangka panjang dan tujuan jangka menengah telah tercapai. Namun demikian, sebelum memulai proses tersebut, panitia penyelenggara perlu memperbaiki databased peserta kursus, sehingga dapat memudahkan proses monitoring dan evaluasi kondisi peserta. Hussain (2013, p.142) mengemukakan buruknya pengelolaan databased tidak hanya berimbas pada proses monitoring dan evaluasi, namun akan berimbas pada proses perencanaan kegiatan selanjutnya. Pada proses perencanaan pelatihan, adanya databased yang baik akan memudahkan pengelola untuk merancang program pelatihan yang berkesinambungan dari level dasar ke level selanjutnya bagi para alumni pelatihan.

Banyaknya peserta yang tidak menyelesaikan kursus dan tidak mengikuti ujian akhir harus menjadi perhatian panitia penyelenggara kursus menjahit. Panitia penyelenggara perlu lebih proaktif untuk mencari penyebab banyaknya peserta yang 
tidak menyelesaikan kursus sehingga dapat melakukan perbaikan atas kinerja penyelenggaraan kursus.

\section{Tutor/Narasumber}

Penyelenggaraan kursus kursus rias pengantin, kursus komputer, dan kursus menjahit di SKB Bantul telah didukung tutor/narasumber yang kompeten di bidangnya. Namun demikian, khusus untuk penyelenggaraan kursus menjahit, perlu dilakukan evaluasi atas kinerja tutor/narasumber mengingat banyaknya peserta yang berhenti mengikuti kursus sebelum kursus berakhir.

Pada penjelasan sebelumnya, telah kita ketahui bahwa tujuan jangka panjang, tujuan jangka menengah, dan tujuan jangka pendek berhasil dicapai dalam penyelenggaraan kursus tata rias pengantin dan tata rias komputer, namun tidak demikian pada penyelenggaraan kursus menjahit. Peserta kursus menjahit bahkan memilih berhenti sebelum mengikuti seluruh tahapan kursus. Fenomena yang terjadi pada penyelenggaraan kursus menjahit tersebut, sedikit banyak melibatkan peranan tutor/narasumber di dalamnya.

Sebelum memulai materi, seorang tutor/narasumber seharusnya dapat menggali terlebih dahulu motivasi para peserta mengikuti kursus. Apabila diketahui bahwa motivasi para peserta kurang, maka pendidik harus dapat menumbuhkan motivasi dan minta belajar peserta. Pendidik harus menarik perhatian peserta sedemikian rupa, sehingga terbangun sebuah kemauan untuk memusatkan perhatian pada pelajaran. Hal tersebut mutlak dilakukan karena apabila terjadi gangguan pada proses memusatkan perhatian pada pelajaran, maka hal tersebut akan menjadi hambatan bagi proses-proses berikutnya dalam tahapan proses belajar.

\section{Sarana Prasarana Penunjang Kursus}

Sarana prasarana kursus belum sepenuhnya mendukung penyelenggaran kursus. Faktor sarana prasana adalah salah satu kelemahan bagi penyelenggaraan kursus tata rias pengantin, kursus menjahit, maupun kursus komputer.

Pada kursus rias pengantin, sarana prasarana yang kurang terutama sarana prasarana penunjang kegiatan praktek seperti kain, sanggul, dan kosmetik. SKB Bantul telah menyediakan sarana prasarana tersebut, namun jumlahnya sangat terbatas sehingga peserta harus memenuhi sendiri kebutuhan perlengkapan prakteknya. Hal tersebut dapat memberatkan peserta, mengingat perlengkapan tersebut harus selalu tersedia pada saat diselenggaraknnya praktek kelas. Peserta umumnya harus menyewa pakaian, sanggul dan atribut lainnya yang tentu saja harganya tidak murah. Demikian pula dengan kosmetik. Kosmetik mutlak diperlukan untuk praktek merias. Selain perlengkapan praktek, peserta harus menyediakan sendiri model untuk dirias dan menanggung biaya-biaya yang berkaitan dengan pengadaan model.

Pada penyelenggaraan kursus menjahit, pada tahun 2012, SKB Bantul belum ditetapkan sebagai TUK Tata Busana/menjahit. SKB Bantul baru ditetapkan sebagai TUK Tata Busana/menjahit pada tahun 2014. Pada penyelenggaraan kursus komputer, SKB Bantul telah memiliki unit komputer yang mencukupi. Namun demikian, unit yang dimiliki sudah tidak sesuai dengan perkembangan teknologi informasi yang ada saat ini. Revitalisasi komputer di SKB Bantul merupakan hal yang prioritas mengingat salah satu tujuan penyelenggaraan kursus komputer adalah untuk mempersiapakan peserta dalam menghadapi dunia kerja. Tanpa menggunakan komputer yang sesuai, maka peserta akan kesulitan menyesuaikan diri dengan tuntutan dunia kerja, apalagi kebanyakan peserta adalah benar-benar peserta pemula yang buta komputer.

Selain unit komputer yang sudah tidak sesuai dengan perkembangan teknologi, SKB Bantul perlu menambah kapasitas jaringan intrenet yang dimilikinya. Internet saat ini sudah menjadi bagian dari kebutuhan hidup manusia. Untuk itu penguasaan internet juga diperlukan peserta dalam pekerjaan sehari-harinya. Menurut penyelenggara kursus komputer, keterbatasan sarana prasana komputer dan internet juga menjadi salah satu hambatan belum ditetapkanya SKB Bantul sebagai TUK Komputer. 


\section{Jurnal Pendidikan dan Pemberdayaan Masyarakat, 3 (1), Maret 2016 - 72 \\ Muhammad Adil Arnady, Iis Prasetyo}

Pendanaan

Pendanaan program belum sepenuhnya mendukung penyelenggraan kursus. Pendanaan kegiatan terbatas pada biaya operasional kegiatan dan tidak mencakup revitalisasi sarana prasarana dan biaya monitoring evaluasi.

Pendanaan merupakan salah satu kekuatan dari penyelenggaraan kursus di SKB Bantul. Seluruh peserta untuk ketiga jenis kursus menyatakan bahwa biaya yang harus dibayarkan untuk mengikuti kursus lebih murah apabila dibandingkan dengan penyelenggara kursus yang lain. Harga yang murah dapat diberikan oleh SKB Bantul karena adanya dukungan dana/subsidi dari pemerintah daerah. Beberapa peserta bahkan tidak dikenakan biaya sama sekali karena adanya bantuan pemerintah.

Walaupun biaya kursus yang murah menjadi kekuatan dari penyelenggaraan kursus, namun biaya tersebut hanya diperuntukkan untuk biaya operasional kegiatan. Tidak terdapat biaya untuk melaksanakan kegiatan monitoring dan evaluasi untuk melihat dampak pelaksanaan program. Dana juga hanya tersedia untuk menyelenggarakan satu kali kursus tiap tahunnya. Dana juga tidak tersedia untuk revitalisasai sarana prasana, sehingga SKB Bantul belum bisa memperbaharui sarana prasarana kursusnya.

Masalah pendanaan pada penyelenggaraan pendidikan nonformal memang masih menjadi kendala tersendiri. Hussain (2013, pp.141-142) menyatakan bahwa alokasi anggaran pada seluruh tingkatan pemerintahan di banyak negara bagi penyelenggaraan pendidikan nonformal terutama pada pendidikan orang dewasa umumnya sangatlah minim apabila dibandingkan dengan alokasi anggaran pendidikan formal. Tak hanya terkait pemenuhan sarana prasarana, pendanaan yang minim akan mempengaruhi pula keluasan cakupan/akses masyarakat kepada penyelenggaraan pendidikan, gaji/ remunerasi serta ketersediaan fasilitator yang kompeten, serta penguasaan atas penerapan teknologi informasi. Hal tersebut menjadi tantangan tersendiri bagi penyelenggara pendidikan nonformal, di samping adanya berbagi permalahan transparansi dan akuntabilitas pengelolaan keuangan.

Dengan segala keterbatasan dana yang ada, penyelenggara kursus di SKB Bantul telah berusaha untuk tetap memberikan pelayanan yang optimal kepada peserta, bahkan dapat menyelenggarakan kelas secara gratis. Namun demikian, belajar pada penyelenggaraan kursus menjahit, biaya yang murah/gratis dapat menjadi ancaman bagi penyelenggaraan kursus. Adanya biaya yang murah/gratis justru membuat peserta tidak termotivasi untuk mengikuti seluruh tahapan kursus dengan baik. Beberapa peserta tidak mengikuti ujian bahkan tidak mengikuti seluruh tahapan kursus. Peserta tidak merasa telah melakukan pengorbanan apapun, sehingga apabila tidak menyelesaikan kursus, peserta tidak merasa dirugikan. Fenomena yang terjadi pada kursus menjahit dapat dijelasakan oleh Soetomo (2011, pp.148-152) sebagai sebuah bentuk antiklimaks dari program pemberdayaan masyarakat. Biaya yang murah bahkan gratis yang malah menurunkan motivasi peserta dalam mengikuti kursus adalah sebuah bentuk .

\section{SIMPULAN DAN SARAN}

Berdasarkan hasil penelitian, dapat disimpulkan hal-hal sebagai berikut.

\section{Kursus Tata Rias Pengantin}

Kursus tata rias pengantin telah tercapai pada tujuan jangka panjang, jangka menengah, dan hasil program sesuai dengan kriteria keberhasilan. Pada tahapan proses, SKB Bantul perlu mengoptimalkan sosialisasi penyelenggaraan kursus terutama melalui media internet. Pelaksanaan, suasana belajar yang dibangun oleh penyelenggara dan narasumber menciptakan pelaksanaan kursus yang mendukung proses belajar peserta didik. Monitoring dan evaluasi, belum dilakukan secara menyeluruh. Monitoring dan evaluasi baru dilaksanakan pada tataran evaluasi pembelajaran. Pada tahapan masukan program telah mendukung terlaksananya penyelenggaraan kursus.

\section{Kursus Menjahit}

Tujuan jangka panjang dan jangka menengah gagal dicapai dari penyelenggara- 
an kursus menjahit. Hasil program kursus menjahit, peserta kursus hanya memiliki kecakapan pribadi dan kecakapan sosial, namun tidak memiliki kecakapan akademik dan kecakapan vokasional.

Pada proses program kecakapan hidup, SKB Bantul perlu mengoptimalkan sosialisasi penyelenggaraan kursus terutama melalui media internet. Pelaksanaan, suasana belajar yang berusaha dibangun oleh narasumber/tutor belum berhasil meningkatkan antusiasme peserta untuk mengikuti seluruh materi pembelajaran. Pada tahapan monitoring dan evaluasi baru dilaksanakan pada tataran evaluasi pembelajaran. Tahapan masukan program telah mendukung terlaksananya penyelenggaraan kursus.

\section{Kursus Komputer}

Tujuan jangka panjang, jangka menengah, dan hasil program berhasil dicapai dari penyelenggaraan kursus komputer sesuai dengan kriteria keberhasilan. Pada proses program, SKB Bantul perlu mengoptimalkan sosialisasi penyelenggaraan kursus terutama melalui media internet. Pada tahapan pelaksanaan, suasana belajar yang dibangun oleh penyelenggara dan narasumber menciptakan pelaksanaan kursus yang mendukung proses belajar siswa. Pada tahapan monitoring dan evaluasi baru dilaksanakan pada tataran evaluasi pembelajaran. Pada tahapan masukan program telah mendukung terlaksananya penyelenggaraan kursus.

Berdasarkan hasil penelitian, berikut ini saran untuk meningkatkan kualitas penyelenggaraan kursus SKB Bantul. (1) Untuk mempersiapkan alumni kursus supaya bisa mempunyai usaha mandiri, SKB Bantul dapat bekerjasama dengan intansi lain untuk mendapatkan modal usaha ataupun program magang bagi peserta kursus yang potensial. Rekomandasi untuk mendapatkan modal usaha dan kesempatan magang dapat diberikan sebagai reward kepada peserta meningkatkan motivasi belajar peserta selama mengikuti kursus. (2) SKB Bantul perlu mengoptimalkan sosialisasi penyelenggaraan kursus melalui media sosial dan perlu memperbaiki tampilan website sehingga lebih infromatif. (3) SKB Bantul perlu melakukan proses monitoring dan evaluasi secara menyeluruh, tak hanya pada tataran evaluasi pembelajaran, namun perlu mencakup monitoring dan evaluasi pada tataran program, terutama untuk dampak jangka menengah dan jangka panjang (outcome) penyelenggaraan kursus. Kegiatan monitoring dan evaluasi tersebut perlu ditunjang. pula dengan databased peserta yang memadai. (4) Untuk mengatasi berbagai persoalan kurangnya sarana prasana, SKB Bantul dapat mengajukan proposal dana kepada lembaga donor seperti Dirjen PAUDNI. Proposal dana juga dapat diajukan dalam bentuk bantuan dana penyelenggaraan kursus sehingga SKB Bantul dapat menyelenggarakan kursus dengan harga yang murah bahkan gratis untuk lebih banyak peserta

\section{DAFTAR PUSTAKA}

Anwar. (2012). Pendidikan kecakapan hidup (life skills education): Konsep dan aplikasi. Bandung: Alfabeta.

Departemen Pendidikan Nasional. (2001). Konsep pendidikan kecakapan hidup (life skill education). (Buku I). Tim Broad Based Education. Jakarta: Depdiknas.

Departemen Pendidikan Nasional. (2002). Pola pelaksanaan pendidikan berorientasi kecakapan hidup melalui BBE untuk PMU. Tim Broad Based Education (BBE) Ditjen Dikdasmen. Jakarta: Ditjen PLS dan PemudaDepdiknas.

Fakhrudin. (2011). Evaluasi program pendidikan nonformal. Semarang: Unnes Press

Hussain, M.S. (2013). Challenges and emerging perspectives in adult education delivery in Nigeria. European Scientific Journal, 9 (13), pp. 138-145, Retrived from http://eujournal.org/index.php/esj/arti cle/view/1045

Ihejirika, J. C. (2012) Utilization of adult and non-formal education programs in combating rural poverty in Nigeria. World Journal of Education, 2 (3), p. 29, Retrived 
Jurnal Pendidikan dan Pemberdayaan Masyarakat, 3 (1), Maret 2016 - 74

Muhammad Adil Arnady, Iis Prasetyo

http://www.sciedu.ca/journal/index.p hp/wje/article/view/1288

Kamil, Mustofa. (2012). Model pendidikan dan pelatihan (konsep dan aplikasi). Bandung: Alfabeta.

Kirkpatrick, D.L., \& Kirkpatrick. J.D. (2006). Evaluating training programs: The four levels (3rd edition). Oakland: BerrettKoehler Publishers

Koontz, H., O'Donnell, C., \& Weihrich, H. (2001). Manajemen. Jakarta: Erlangga

Nelson-Jones, R. (2005). Practical counselling and helping skills. New York: SAGE Publications Ltd.
Soetomo. (2011). Pemberdayaan masyarakat: Mungkinkah muncul antitesisnya?. Yogyakarta: Pustaka Pelajar.

Sudjana, D. (2006). Evaluasi program pendidikan luar sekolah untuk pendidikan nonformal dan pengembangan sumber daya manusia. Bandung: Remaja Rosdakarya

Suprijanto.(2012). Pendidikan orang dewasa dari teori hingga aplikasi. Jakarta: PT Bumi Aksara

Supriadi, D., \& Jalal, F. (2005). Reformasi pendidikan dalam konteks otonomi daerah. Jakarta: Adicita Karya Nusa 